\title{
Poor comprehension of colon preparation process in an Appalachian population
}

This article was published in the following Dove Press journal:

Clinical and Experimental Gastroenterology

29 September 2010

Number of times this article has been viewed

\section{Indraneel Reddy' \\ Manan Jhaveri' \\ Uday Shankar ${ }^{2}$ \\ Lisbeth Selby'}

'University of Kentucky, Department of Internal Medicine, Division of Digestive Diseases and Nutrition, Lexington, KY, USA; ${ }^{2}$ Hazard Appalachian Regional Healthcare, Hazard, KY, USA
Correspondence: Lisbeth Selby University of Kentucky Medical Center, Division of Digestive Diseases and Nutrition, MN 649, 800 Rose St, Lexington, KY 40536, USA Email laselb0@uky.edu
Abstract: Clear liquids are often part of colonoscopy preparation instructions, regardless of the active cleansing agent. Poor understanding of this facet may yield poor preparation with delays in management. We studied comprehension of this facet of colon preparation in an Appalachian population. Our survey contained demographic items and a list of food items from which subjects could select clear liquids. In Phase I, no prompting was given. In Phase II, subjects reviewed the definition of clear liquids and examples a few minutes before the survey. For Phase III, the survey contained the definition of a clear liquid and examples. Persons about to undergo colonoscopy and companions who escorted them were surveyed, since many persons have help during the preparation process. With the Fisher exact probability test, we compared the association of accurately selecting clear liquids $\geq$ or $<80 \%$ of the time with education $>$ or $\leq 12$ th grade, age, gender, and subject's stated understanding of preparation. Mean age for all subjects was 52 years and $59 \%$ of subjects were female. The majority had $\leq 12$ years of education. Most subjects reported understanding their preparation instructions and yet the minority had $\geq 80 \%$ accuracy on clear liquid selection (range 6\%-16\%). Phases I-III represent a continuum of progressively more accessible information about clear liquids. Comparison across the 3 phases, for both patients and companions, did not reveal significantly improved clear liquid selection. Multivariate analyses of the above variables, with \% correct answer as the dependent variable for all the subgroups, did not reveal any significant associations. Persons from Appalachia do not seem to understand a key portion of the colon preparation process. We demonstrate no significant predictors of understanding the clear liquid aspect of colon preparation. Simple measures to augment comprehension have no clinically significant effect.

Keywords: clear liquids, colonoscopy, Appalachian population

\section{Background}

Thousands of colonoscopies are performed everyday around the world. Adequate preparation of the colon is an essential step before colonoscopy. Few studies have examined comprehension of the colon preparation process. Study in this area is complex since there are many active cleansing agents. With most colonoscopy preparation regimens the patient receives instructions about clear liquids. However, not all patients may understand the clear liquid component of the preparation instructions, resulting in poor quality preparation with subsequent delays in diagnosis and treatment.

In general, patient comprehension of medical instructions is poor since most Americans read at the equivalent of an 8 th or 9 th grade level and yet most health care materials are written at a 10 th grade level. ${ }^{1}$ Poor health literacy has been linked to low educational attainment and income levels., ${ }^{2,3}$ 
The region of the United States known as Appalachia includes a 205,000-square-mile largely rural region that follows the Appalachian Mountains from New York to Mississippi. According to 2000 US Census data, it is home to 24.8 million persons. ${ }^{4}$ The population of Appalachia has been affected by increased rates of poverty and low educational attainment. ${ }^{1,4}$

We aimed to study comprehension of the clear liquid aspect of the colon preparation process in an Appalachian population. We anticipated poor comprehension in this population as observed in other populations. ${ }^{5}$ We anticipated that simple interventions which might theoretically increase comprehension would have minimal effect.

\section{Methods}

The institutional review boards of both the University of Kentucky and Hazard Appalachian Regional Healthcare approved this study.

We surveyed patients awaiting colonoscopy in an outpatient endoscopy center located in Hazard, KY, a rural Appalachian community. We also surveyed the persons who accompanied them to the exam since these persons may have provided the patient assistance during the preparation process.

Our anonymous survey contained demographic items and a list of food items from which subjects could select the clear liquids. In Phase I, no prompting was given other than instructions for clinical care. In Phase II, subjects reviewed the definition of clear liquids and examples a few minutes before the survey. For Phase III, the survey contained the definition of a clear liquid and examples.

The exact phrase used to explain clear liquids was: Clear liquids are liquids you can see through like apple juice, clear broth, black coffee, 7-up ${ }^{\circledR}$, or tea.

The list of food items was as follows:

\begin{tabular}{|c|c|c|}
\hline Water & Chicken noodle soup & Whole milk \\
\hline Cereal & Vegetable soup & Pizza \\
\hline \multirow[t]{2}{*}{ Crackers } & Tomato soup & Grape \\
\hline & & Popsicle $^{\circledR}$ \\
\hline Coffee & Bread & Ice cream \\
\hline Eggs & Fruit & Skim milk \\
\hline Fish Sandwich & Jello $^{\circledR}$ & Beer \\
\hline Pudding & $\operatorname{Coke}^{\circledR} /$ Pepsi $^{\circledR}$ & Tea \\
\hline Orange juice & Sprite $^{\circledR}$ & Spaghetti \\
\hline
\end{tabular}

Scoring was calculated as follows: (\# correct-\# incorrect)/ total \# possible correct answers $\times 100$. Correct answers were water, Sprite ${ }^{\circledR}$, tea, Jello ${ }^{\circledR}, \mathrm{Coke}^{\circledR} / \mathrm{Pepsi}^{\circledR}$, and coffee. Answer choices beer and grape Popsicle ${ }^{\circledR}$ were not considered correct or incorrect as these are technically clear liquids but should not be taken prior to the procedure.
With the Fisher exact probability test, we compared the association of accurately selecting clear liquids $>$ or $<80 \%$ of the time with the following variables: 1 )education $>$ or $<12$ th grade, 2) age, 3) gender, and 4) subject's stated understanding of preparation.

\section{Results}

See Tables 1-3 for summaries of the subgroup demographics and clear liquid selection accuracy.

See Tables 4 and 5 for comparisons of clear liquid selection accuracy across the phases of the study in both patients and companions.

Multivariate analyses of education, age, gender, and subject's report of understanding preparation instructions, with \% correct answer as the dependent variable for all the subgroups did not reveal any significant associations. See Table 6 for patient results combined for all phases. See Table 7 for companion results combined for all phases. Similar findings were noted for individual phase analyses for both patients and companions.

\section{Discussion}

We recognize that the phenomenon of poor colonic preparation has been well described but feel our findings shed light on a minimally studied facet of colon cleansing, namely patient comprehension. Although we could have chosen to study the entire colon preparation process, this is not practical in an actual clinical setting since there are many regimens employed for colon cleansing. However, many endoscopy units provide the definition and examples of clear liquids as part of their colon preparation instructions. We demonstrate that, even with the clear liquid definition and examples immediately accessible to subjects (Phase III), most cannot accurately select clear liquids, which implies poor comprehension as opposed to poor recall. Perhaps a set list of food items permitted during colonoscopy preparation would resolve this problem but this concept remains to be tested.

Table I Phase I demographics and clear liquid selection accuracy

\begin{tabular}{llll}
\hline & $\begin{array}{l}\text { Patients } \\
(\mathbf{n}=\mathbf{5 0})\end{array}$ & $\begin{array}{l}\text { Companions } \\
(\mathbf{n = 5 0 )}\end{array}$ & $\begin{array}{l}\text { Totals } \\
(\mathbf{n}=\mathbf{1 0 0})\end{array}$ \\
\hline Mean age & 54 & 50 & 52 \\
$\begin{array}{l}\text { Male gender \% } \\
\text { Education years \% }\end{array}$ & 34 & 50 & 42 \\
$\quad$ & 56 & 57 & 56 \\
$\quad>12$ & 44 & 43 & 43 \\
$\begin{array}{l}\text { Reported } \\
\text { understanding } \\
\text { of instructions \% }\end{array}$ & 100 & 46 & 73 \\
$\geq 80 \%$ correct & $6 \%$ & & \\
\hline
\end{tabular}


Table 2 Phase II demographics and clear liquid selection accuracy

\begin{tabular}{llll}
\hline & $\begin{array}{l}\text { Patients } \\
(\mathbf{n}=\mathbf{5 0})\end{array}$ & $\begin{array}{l}\text { Companions } \\
(\mathbf{n}=\mathbf{5 0})\end{array}$ & $\begin{array}{l}\text { Totals } \\
(\mathbf{n}=1 \mathbf{0 0})\end{array}$ \\
\hline Mean age & 56 & 49 & 52 \\
$\begin{array}{l}\text { Male gender \% } \\
\text { Education years \% }\end{array}$ & 46 & 40 & 43 \\
$\quad$ & & & \\
$\quad \leq 12$ & 63 & 66 & 64 \\
$\quad>12$ & 37 & 34 & 35 \\
$\begin{array}{l}\text { Reported } \\
\text { understanding } \\
\text { of instructions \% }\end{array}$ & 96 & 62 & 79 \\
$\geq 80 \%$ correct & $12 \%$ & $10 \%$ & $11 \%$ \\
\hline
\end{tabular}

Table 3 Phase III demographics and clear liquid selection accuracy

\begin{tabular}{|c|c|c|c|}
\hline & $\begin{array}{l}\text { Patients } \\
(n=50)\end{array}$ & $\begin{array}{l}\text { Companions } \\
(n=50)\end{array}$ & $\begin{array}{l}\text { Totals } \\
(n=100)\end{array}$ \\
\hline Mean age & 55 & 50 & 52 \\
\hline Male gender \% & 40 & 39 & 39 \\
\hline \multicolumn{4}{|l|}{ Education years \% } \\
\hline$\leq 12$ & 64 & 55 & 56 \\
\hline$>12$ & 36 & 45 & 40 \\
\hline $\begin{array}{l}\text { Reported } \\
\text { understanding } \\
\text { of instructions \% }\end{array}$ & 98 & 54 & 76 \\
\hline$\geq 80 \%$ correct & $16 \%$ & $12 \%$ & $14 \%$ \\
\hline
\end{tabular}

Table 4 Comparison of patient clear liquid selection accuracy from 3 phases

\begin{tabular}{llll}
\hline $\begin{array}{l}\text { Phases } \\
\text { compared }\end{array}$ & $\begin{array}{l}\geq \mathbf{8 0 \%} \\
\text { correct }\end{array}$ & $\begin{array}{l}<\mathbf{8 0} \% \\
\text { correct }\end{array}$ & $\begin{array}{l}\text { OR }(95 \% \mathrm{CI}), \\
\text { P value }\end{array}$ \\
\hline II & 6 & 44 & $2.13(0.50,9.06), 0.27$ \\
I & 3 & 47 & \\
III & 8 & 42 & $2.98(0.74$, II.98), 0.I I \\
I & 3 & 47 & \\
II & 6 & 44 & 0.7 I $(0.22,2.23), 0.56$ \\
III & 8 & 42 & \\
\hline
\end{tabular}

Table 5 Comparison of companion clear liquid selection accuracy from 3 phases

\begin{tabular}{llll}
\hline $\begin{array}{l}\text { Phases } \\
\text { compared }\end{array}$ & $\begin{array}{l}\geq \mathbf{8 0 \%} \\
\text { correct }\end{array}$ & $\begin{array}{l}<\mathbf{8 0 \%} \\
\text { correct }\end{array}$ & $\begin{array}{l}\text { OR }(\mathbf{9 5} \% \mathrm{CI}), \\
\text { P value }\end{array}$ \\
\hline II & 5 & 45 & I $(0.27,3.69)$, NA \\
I & 5 & 45 & \\
III & 6 & 44 & I.22 $(0.35,4.3$ I $), 0.1$ I \\
I & 5 & 45 & \\
II & 5 & 45 & $0.8 \mathrm{I}(0.23,2.86), 0.1$ I \\
III & 6 & 44 & \\
\hline
\end{tabular}

Table 6 Multivariate analyses of predictors of clear liquid selection accuracy of $\geq 80 \%$ by patients

\begin{tabular}{lllll}
\hline & \multicolumn{2}{l}{ OR $\mathbf{( 9 5} \mathbf{~ C l})$} & & $\boldsymbol{P}$ value \\
\hline Education & 1.750 & 0.575 & 5.324 & 0.3245 \\
Age & 1.020 & 0.977 & 1.065 & 0.3712 \\
Gender & 0.893 & 0.296 & 2.696 & 0.8408 \\
Had procedure & 0.493 & 0.157 & 1.548 & 0.2256 \\
\hline
\end{tabular}

Table 7 Multivariate analyses of predictors of clear liquid selection accuracy of $\geq 80 \%$ by companions

\begin{tabular}{lllll}
\hline & \multicolumn{2}{l}{ OR $\mathbf{( 9 5} \mathbf{~ C l})$} & $P$ value \\
\hline Education & 1.496 & 0.523 & 4.276 & 0.4525 \\
Age & 0.998 & 0.963 & 1.033 & 0.9013 \\
Gender & 0.816 & 0.279 & 2.385 & 0.7102 \\
\hline
\end{tabular}

Unmeasured factors could have affected our results. For example, we did not systematically measure whether and how a subject may have received prior instruction about clear liquids. We did not ask whether a subject is a health care worker and therefore has work-related understanding of clear liquids. There could have been imbalances among the subgroups, which obscured minor differences. However, uniformly poor accuracy suggests that this was not the case.

We did not correlate survey answers to preparation adequacy. With increasing emphasis on flat colonic lesions and rising health care costs, maximizing the preparation quality for every exam is an important goal. ${ }^{6,7}$ We can only infer the correlation of our findings to the common clinical problem of poor preparation, since taking a foodstuff other than a clear liquid post-colon preparation would theoretically put residue back into the colonic lumen.

Unfortunately, neither of our simple interventions (see description of Phases II and III) had an appreciable effect in our groups of 50 subjects each. We feel these are clinically relevant sample sizes and that, therefore, if an effect of our intervention exists, the magnitude must be small. In other words, if an effect of an intervention such as ours were to be useful and practical in a real clinical setting, we believe a noticeable difference should be demonstrable with fewer than 50 patients.

It is tempting to assume our results apply only to educationally or otherwise socioeconomically disadvantaged populations such as the study group. However, data from our group suggests this is a problem of much broader scope and seems to affect groups with education levels higher than the national average. ${ }^{5}$ Moreover, reading comprehension, which is intricately linked with health literacy, is declining even among highly educated persons. ${ }^{8}$

Persons from Appalachia, like persons outside the region, do not seem to understand a key portion of the colon preparation process. We demonstrate no significant predictors of understanding the clear liquid aspect of colon preparations. In addition, simple measures to augment comprehension have no clinically significant effect.

\section{Disclosure}

The authors have no financial disclosures to declare and no conflicts of interest to report. 


\section{References}

1. Denham SA, Rathbun A. Appalachian Rural Health Institute Community Health Assessment. Appalachia: an overview of health concerns and health literacy [online]. 2005. Accessed 2010 Aug 26. Available from: http://www. oucom.ohiou.edu/arhi/presentations/appalachia_overview.pdf

2. Jeppesen KM, Coyle JD, Miser WF, et al. Screening questions to predict limited health literacy: a cross-sectional study of patients with diabetes mellitus. Ann Fam Med. 2009;7(1):24-31.

3. Ginde AA, Weiner SG, Pallin DJ, et al. Multicenter study of limited health literacy in emergency department patients. Acad Emerg Med. 2008;15(6):577-580

4. Appalachian Regional Commission [online]. Accessed 2010 Aug 26. Available from: http://www.arc.gov/index.do?nodeId=2
5. Paranjape S, Nick1 N, Selby LA. Understanding of clear liquid instructions as part of colonoscopy preparation. Am J Gastroenterol. 2008;103:A1318.

6. Sung JJ, Lau JY, Young GP, et al. Asia Pacific consensus recommendations for colorectal cancer screening. Gut. 2008;57(8):1166-1176.

7. The Henry J Kaiser Family Foundation. US Healthcare costs [online]. Accessed 26 Aug 2010. Available from: http://www.kaiseredu.org/topics_ im. asp? imid $=1$ \&parentid $=61 \&$ id $=358$

8. National Endowment for the Arts. To read or not to read: a question of national consequence [online]. Accessed 2010 Aug 26. Available from: http://www.nea.gov/research/toread_execsum.pdf

\section{Publish your work in this journal}

Clinical and Experimental Gastroenterology is an international, peerreviewed, open access journal, publishing all aspects of gastroenterology in the clinic and laboratory, including: Pathology, pathophysiology of gastrointestinal disease; Investigation and treatment of gastointestinal disease; Pharmacology of drugs used in the alimentary tract;
Immunology/genetics/genomics related to gastrointestinal disease. This journal is indexed on CAS. The manuscript management system is completely online and includes a very quick and fair peer-review system. Visit http://www.dovepress.com/testimonials.php to read real quotes from published authors.

Submit your manuscript here: http://www.dovepress.com/clinical-and-experimental-gastroenterology-journal 